\title{
Risk Aversion, Behavioral Finance and Green Bonds for the Sustainability of Environmental Assets in
} Peru

\author{
Edelina Coayla \\ Faculty of Economic Sciences, Universidad Nacional Federico Villarreal, Peru \\ edelinacoayla@yahoo.es, acoayla@unfv.edu.pe
}

\begin{abstract}
The study objective is to investigate the relationship between behavioral finance and the decision to invest in green bonds for the sustainability of environmental assets in Peru. A survey with behavioral questions was applied to a sample of 54 respondents between July and October 2019. Spearman's rank correlation, independence tests, and logistic regression were used. Significant negative correlations were found between the level of education and risk aversion, and between age and risk aversion. A negative relationship was found between risk aversion and the feeling of comfort when investing in stock market instruments such as green bonds. Aversion to a loss in investment decisions was validated; most people choose low-risk fixed income instruments despite feeling safe investing in stocks. According to the logistic regression, the decision to invest in green bonds to improve environmental quality is explained by the variables "green bond rating" and "feeling of comfort (satisfaction) investing in green bonds."
\end{abstract}

Keywords: Behavioral finance, green bonds, risk aversion, loss aversion, environmental sustainability.

\section{Introduction}

Financial markets behave with limited economic rationality. Therefore, they are complemented by the emotions of investors when they make decisions in a context of uncertainty. Faced with the question of how to finance environmental goods, the possibility arises of using behavioral finance to promote sustainability, of these environmental assets. Richard Thaler is regarded as a pioneer of behavioral finance, having won the 2017 Nobel Prize for Economics in recognition of his contribution to the study of the behavior of financial markets. Among his innovations, Thaler introduced pioneering models of investor psychology to explain empirical challenges such as the predictability of stock prices. The theoretical basis of this field was proposed by the psychologists Kahneman and Tversky (1979), whose "prospect theory" was an alternative to the neoclassical economic theory of expected utility. According to behavioral finance, people typically act irrationally when making risky decisions. Thaler (1999), in his paper "The End of Behavioral Finance", argues that economists routinely incorporate as much "behavior" in their models as they observe in the real world and that doing otherwise would be irrational. Thaler referred to the 2013 Nobel laureate in Economics, Robert Shiller, whose study (1981) sparked a long and complex debate among financial economists; however, his conclusion is now generally thought to be correct.

Stock and bond prices are more volatile than proponents of efficient rational market theory would predict. According to Ahmad et al. (2017), understanding the origin of behavioral biases, causes, and effects requires interdisciplinary perspectives from the fields of psychology, sociology, and biology. In this vein, behavioral finance studies the behavior of investors (Kankipati \& Sireesha, 2017). The focus is justified because behavioral finance provides more knowledge about the role that emotions play in optimal decision-making in the context of uncertainty and risk, the concept of "loss aversion" being innovative in prospect theory, in comparison with the neoclassical approach of risk aversion. Furthermore, cognitive biases and "nudges" may affect asset prices. Finally, it is important to guide Peru to being a low carbon economy; to encourage the country to channel more financial resources to reducing pollution; to complement economic rationality with the "emotional" behavior of economic agents and to nudge investors toward green financial assets. The objective of the study is to investigate the relationship between behavioral finance and the decision to invest in green bonds for the sustainability of environmental assets in Peru. Given the limited prior research on behavioral environmental finance, this study contributes to investigating the relationship between behavioral finance and green bonds as an environmental financing instrument. 


\section{Literature Review}

In their empirical study, Paraboni et al. (2018) found an association between market sentiment and risk. This implies that the behavioral aspect of risk management should not be ignored, and the authors recommend that future studies further explore this relationship. Bolsas \& Mercados Españoles-BME (2017) predicts that 3.9 trillion dollars a year will be invested in advanced countries to finance sustainable development until 2030. In July 2017, the BME's corporate debt market, the AIAF Fixed-income Market-AIAF, has admitted a "green bond" issue from the Spanish state-owned railway company with a value of 600 million Euros. The issue has an expected maturity of six years and will pay interest of $0.8 \%$ per year. The unit face value of the securities is 100,000 Euros and is intended for institutional investors. Green bonds are a financial asset associated with sustainable financing and investment criteria. With regard to investment biases, conservatism bias occurs when people make investment decisions using old information in their mind (often based on past experiences) instead of updating to the new information available in the market (Rahim et al., 2019). Candraningrat, et al. (2018) examined framing information, the disposition effect, and the interaction between the two in investment decisions made by investors when predicting stock prices. Eighty individual investors from the Bali community participated in their experiment, based on a non-probability sampling method with an intentional sampling technique. They found that investors given a positive reporting framework will predict higher stock prices than investors given a negative reporting framework. They also confirmed that the information received by investors contributes to the maximum effect of the provision and that the effect of this provision is influenced by the framing of the information received.

Finally, they observed that there is no difference in behavior when making investment decisions based on gender and investment experience, while there is a difference in the level of education of the participants. Gupta (2018), using a sample of 23,301 firms per year from 43 countries, found that an improvement in environmental practices leads to a reduction in the implicit cost of capital, especially in countries where governance at the national level is weak. He also found that most of the benefits come from reducing emissions and unnecessary wastage of resources. According to a report by the Green Finance Taskforce (2018), in the transition to a low-carbon economy, the United Kingdom (UK) has led the world in reducing its emissions without sacrificing family living standards. Since 1990, the country has reduced emissions by more than $40 \%$, while its economy has grown by two-thirds: the best performance in the G7. The challenge is, first, to advance London as the world's leading center for green finance and, second, to deliver on the UK's clean growth strategy. One of the Green Finance Taskforce's recommendations is the issuance of a green sovereign bond similar to the French equivalent, valued at 9.697 trillion Euros, as a component of the UK's comprehensive capital raising plan. According to the Mexican Carbon Platform (2018), the Lima Stock Exchange (BVL), together with the Embassy of the United Kingdom in Peru and the MéxiCO2 platform, promotes the green bond market in Peru for the financing of projects with a positive impact on the environment. According to the Climate Bonds Initiative (2019), the first green bond in Latin America and the Caribbean was issued in December 2014 by the Peruvian wind-farm operator Energía Eólica, an indirect subsidiary of the energy multinational Contour Global.

The 204 million US dollar bond was used to refinance the Cupisnique and Talara wind farms. Candraningrat et al. (2018) used direct economic actors (investors) as participants in their experiment, which consisted of 80 active investors in Denpasar Bali, grouped into four treatment groups. They demonstrated that the disposition effect has a significant effect on investor behavior in investment decision-making marked with the prediction price. Martins et al. (2018) investigated the use of games among those trading in Brazil's B3 stock exchange. The tools for simulating stock market operations were the World Wide Web with Metatrader and Trading View software. The decision-making variables taken into account were based on fundamental, technical, and graphical analyses. Interacting within the virtual environment of the B3, the participants in the game (students of a course on stock-market operations) were organized into groups, with some moments of collective decision-making and others of individual decision-making. The game had an end date, and rules were established rules to determine the results; that is, the scores determined the winners and losers of the game based on the strategy adopted by each student trading in the B3. The students were evaluated by the financial market, without interference from the professor. There was a dropout rate of $50 \%$ among the initial total of 32 students throughout the course, attributed to the "rigors" of this elective course. Another possibility for this rate may be related to an aversion to uncertainty, risk and loss (Kahneman \& Tversky, 
1979), and to the lack of prior knowledge of financial operations since most of the students who dropped out were majoring in courses outside the area of finance.

The size of the pilot group ( $\mathrm{N}=11$ ) in Endress (2018) proved appropriate in terms of manageability and explanatory, power; however, more data points and coverage of more market phases (bull and bear markets) could help increase the quality of their experiment. Their main experiment was conducted over more than five weeks. All participants were interviewed to provide them with a deeper understanding of the decisionmaking process and to improve the design of the planned experiment. As a result, all agreed that the questions were easy to understand, and felt able to estimate whether the stock price was going up or down. The design and focus of the main experiment were similar in principle to the design of the pilot test (Endress, 2018); there were only a few changes, including an improved online questionnaire, more interview questions, and a requirement that participants enter the target price not as the total amount in Euros but as a change in percentage. Since it was also necessary to keep in touch with all participants for the three-month duration and to allow a moderate dropout quota, an initial panel number of approximately ten participants $(\mathrm{N}=10)$ seemed appropriate. A key criterion for selection was to ensure the diversification of the group in terms of age, gender, level of education, and professional background, etc. Puaschunder (2018) reviewed and proposed how to use mental heuristics, biases, and nudges in the finance domain to make gains in the markets. Howarth and Roberts (2018) critically evaluate the impact of the Green Deal.

On shaping pro-environmental behavior and present the results of two government-funded projects to encourage the adoption of the Green Deal in England, to reduce carbon emissions and improve domestic energy efficiency. They presented the discussion of two case studies, one in Cambridgeshire and the other in Suffolk, UK. To encourage early adoption of the Green Deal, the government made available $£ 10$ million for competition by local authorities, of which Cambridgeshire received $£ 75,000$ and Suffolk received £98,000. Both local authorities used the funds to offer a free Green Deal. Evaluation thereof was decided in response to very early indications from potential Green Deal customers that the cost of the evaluation was a barrier to their participation in the scheme. From a survey of 547 male and female Arab investors in Saudi Arabia and Jordan, Salem (2019), using the Wilcoxon signed-rank test and the Mann-Whitney U test, found that Arab women are more risk-averse and have a lower tolerance for financial risk compared to Arab men; this was explained in part by lower levels of investment literacy, in addition to political uncertainty in the Arab region. The readiness effect (DE) describes the willingness of winners to sell too early and the willingness of losers to hold for too long. Sarmiento et al. (2019) found that market participants with the highest disposition effect (SD) tend, on average, to be those with the lowest cumulative return, to have the smallest value portfolios, to be the least durable, and have the highest coefficient of variation.

\section{Methodology}

Temporal and Spatial Scope: The study covers behavioral finance for the sustainability of environmental assets. Universe: Behavioral finance for public environmental assets; unit of analysis: Green bonds. Because green bonds were first issued only recently and data on their impacts on environmental quality in Peru is scarce, primary information was collected through an online questionnaire. The target population was a diversified group composed of individuals from the business, environmental, and engineering specialties of academia (undergraduates and graduates); professionals from the public and private sector; and finance experts. In each case, the participants were from the south, center, and north of Peru. The sample size is justified by the recent issuance of green bonds in Peru, their scarcity, and the limited public knowledge about them. Nonparametric statistical tests were applied to qualitative data obtained from the survey since the probability distribution of the study variables is generally unknown.

Data Collection Techniques: Secondary information on green finance. A survey containing 13 questions (closed Likert-type except for the last question, "What option do you feel would contribute to the sustainability of environmental capital via the stock market?") was applied online from July to October 2019 to individuals who were over 18 years old, educated to university level (from current undergraduates to PhD graduates), and representative of southern, central, and northern Peru. The respondents were students and graduates from the disciplines of business sciences, environmental sciences, and engineering; public and private sector professionals; and experts in finance and the stock market. The reliability of the questions in 
the questionnaire was evaluated based on the database of a sample of $n=54$ valid surveys (four were discarded due to repeated responses) and using the SPSS statistical software. The relationship between behavioral finance and environmental assets was discerned through an analysis of the survey data.

\section{Results and Discussion}

Green bonds, as fixed-income debt instruments, are used to finance or refinance new or existing projects that are eligible as "green projects." Their issuance requires a second opinion report or a climate bonds certificate.

Table 1: Projects Eligible for Financing with Green Bonds, Peru

\begin{tabular}{l}
\hline Sector / Project \\
\hline Water management \\
Waste management \\
Renewable energy \\
Energy efficiency \\
Afforestation \\
Farming \\
Bioenergy \\
Clean transport \\
Green buildings \\
Others.
\end{tabular}

Source: Lima Stock Exchange

The green bond issuers in Peru are Productos Tissue del Perú S.A.C. and the Corporación Financiera de Desarrollo S.A. (COFIDE). Protisa Peru is a subsidiary of CMPC Tissue, itself a subsidiary of Empresas CMPC, one of the largest wood products manufacturers in the world. CMPC Protisa has issued green bonds to finance or refinance projects to improve the environmental efficiency of its paper mills in three areas: energy efficiency, pollution prevention and control, and sustainable water management. CMPC manages more than 1 million hectares of forest assets in Chile, Brazil, and Argentina spread among plantations, preserved native forests, and the high-value protected areas. It was also about the issuance of green bonds and environmental sustainability in Peru. Then, the relationships between the study variables were statistically compared using non-parametric statistical methods and logistic regression, and, finally, the results were interpreted and discussed in the framework of behavioral economics. From these forests, CMPC harvests more than 17 million cubic meters of wood annually. Sustainalytics, certified by the Climate Bonds Standard Board as a verifying organization, has evaluated Protista Peru to provide a "second-party opinion" on green and sustainable bond frameworks, verifying that it is well-positioned to issue green bonds. In 2018, Sustainalytics was recognized as the largest external verifier by the Climate Bond Initiative, as well as for environmental funding. The Lima Stock Exchange made the first public offer of a green bond on October 22, 2018. The instrument was issued by the paper company Protisa Peru for 100 million soles for a term of six years and an emission rate of $6.625 \%$.

To refinance sustainable projects at its plants in Cañete (energy efficiency and water treatment) and Santa Anita in Lima (water treatment). The demand came from institutional investors (pension fund managers, insurance companies, and others). COFIDE, Peru's national development bank, issued the county's first green bond in May 2019, at 100 million soles, a three-year term, and a rate of 5.125\%; the fund in its entirety will be allocated to refinancing two eligible green projects in the "renewable energy projects" category, with the following result indicators: 1) capacity of the renewable energy plant(s) built or rehabilitated (MW); 2) annual generation of renewable energy in $\mathrm{MWh} / \mathrm{GWh}$ and with impact indicators, the annual GHG emissions reduced/avoided in tons of $\mathrm{CO} 2$ equivalent. Vigeo Eiris, according to its Environmental, Social and Governance assessment methodology ("Second Parties Opinion") considers COFIDE's green bond to be consistent with the challenges of environmental responsibility. In April 2019, Consorcio Transmantaro S.A. issued international green bonds totaling 400 million dollars to finance projects related to renewable energy, energy efficiency, biodiversity conservation, and reduction of polluting emissions (with an expiration date of 04-16-2034 and an annual interest rate of 4,700\% ). To date, it is the only energy transmission company in Latin America to have conducted an unsecured green bond issue. In September 2019, the Lima Stock 
Exchange (BVL) announced the incorporation of four Peruvian companies in SAM's new Dow Jones Sustainability MILA Pacific Alliance Index: Cementos Pacasmayo, Rimac Seguros y Reaseguros, Southern Copper Corporation and Unión Andina de Cements (Unacem), in addition to Ferreycorp, which has been part of this referred index since 2017.

Relationship / Association Tests Based on Primary Data: The reliability analysis of the questionnaire yielded a Cronbach's Alpha of $\alpha=0.711$, signaling good reliability. For the sample size $n=54$, the Kolmogorov-Smirnov normality test statistic indicates that most variables do not have a normal distribution (at the $5 \%$ significance level).

Table 2: Spearman's Correlations between Financial and Environmental Variables, Peru, 2019

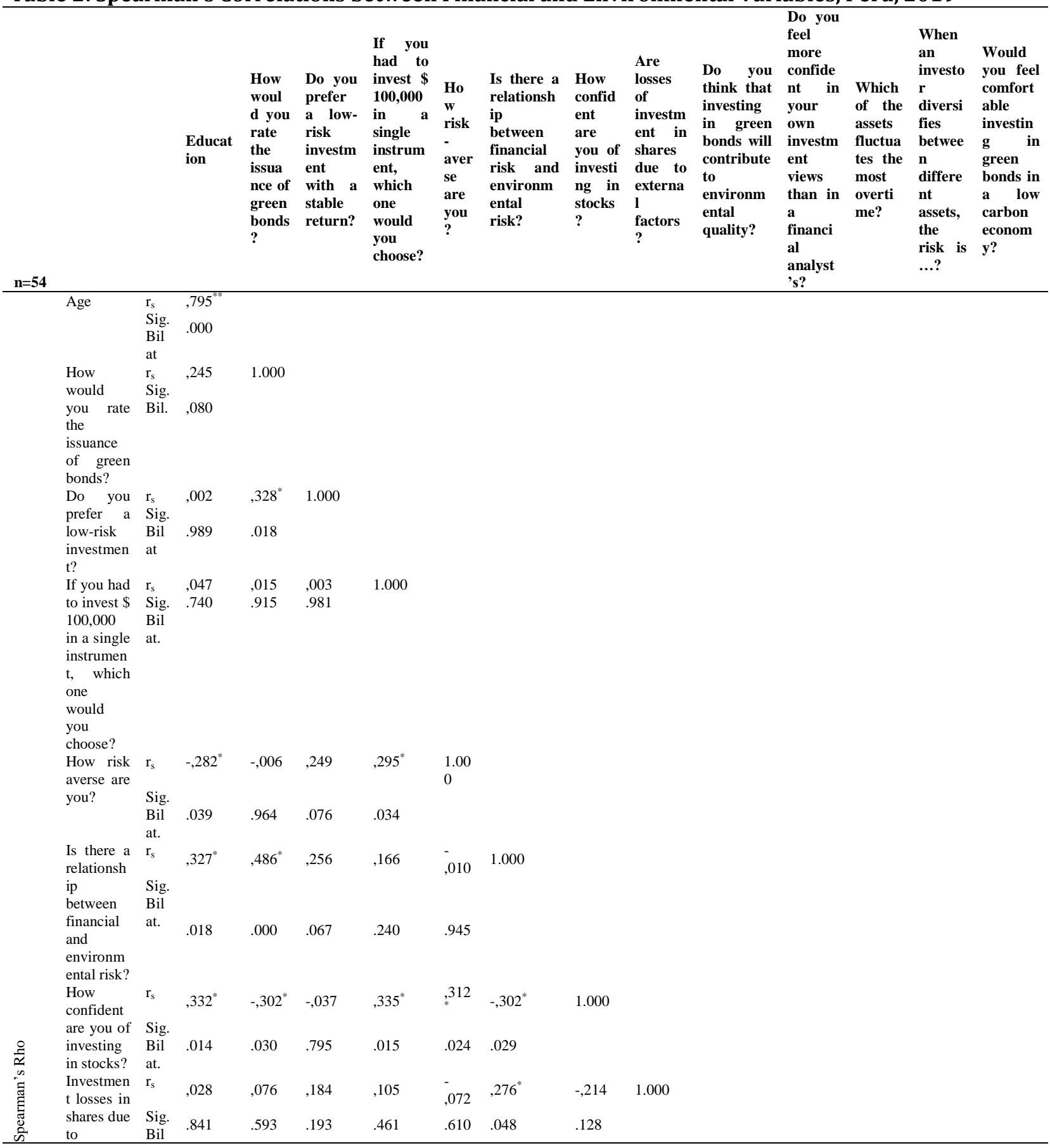




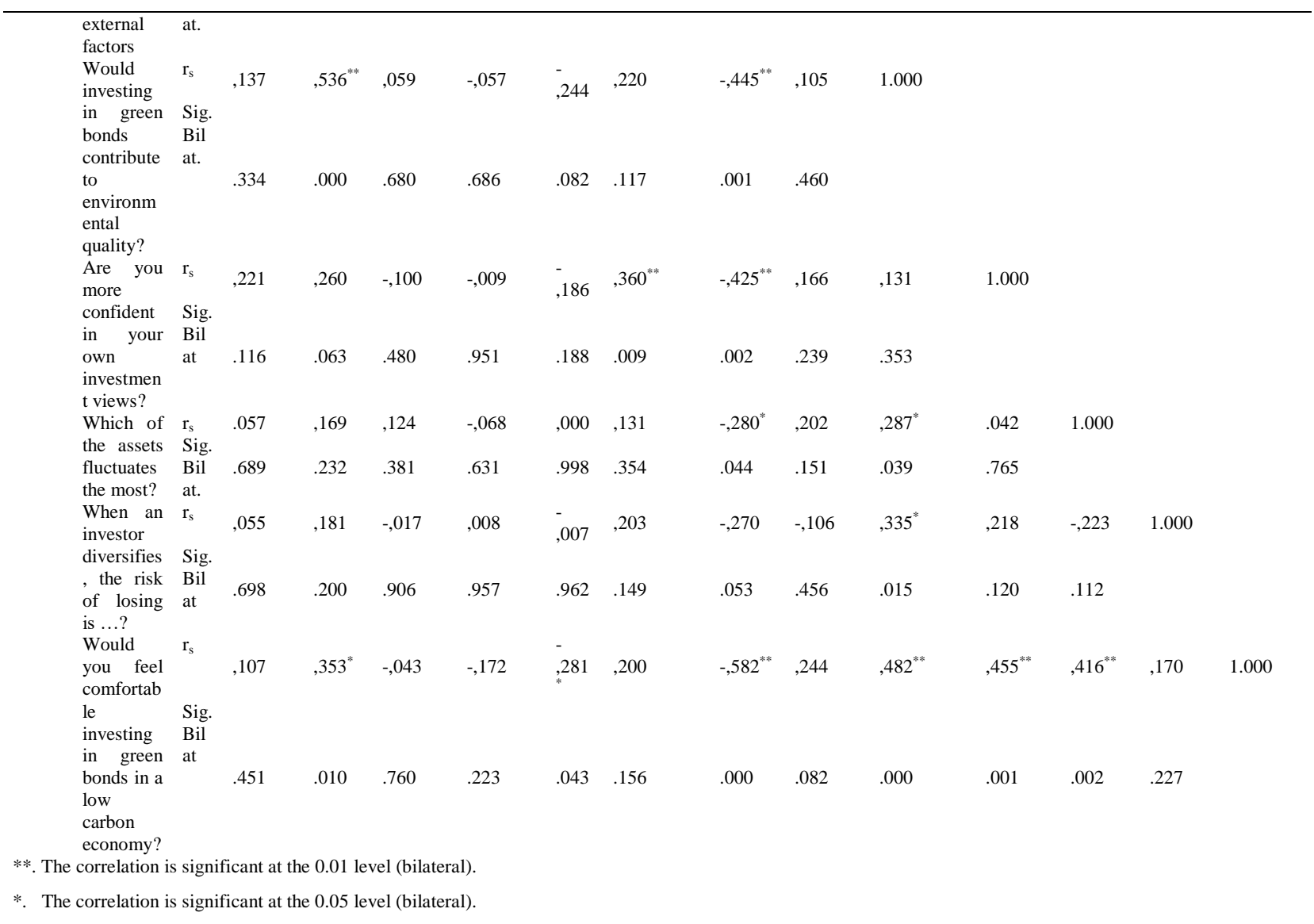

Analysis of the Relationships between Financial and Environmental Variables: In this study, a survey was applied to 54 people over 18 years of age with a university education (ranging from undergraduate students to professionals with $\mathrm{PhD}$ degrees). A significant negative correlation was found between educational level and risk aversion; the higher the level of education of the respondent, the less risk-averse their behavior $(\alpha=5 \%)$. Moreover, the greater the level of education, the more confident they feel about investing in stocks. Similarly, Candraningrat et al. (2018), found differences between the level of education of the participants and their behavior in investment decisions. It was also corroborated that respondents with a more advanced academic degree and knowledge of both finance and environmental assets are more likely to take into account the existence of a close relationship between financial risk and environmental risk (Table 2). A negative correlation was found, at a significance level of 5\%, between age and risk aversion; that is, the older the person, the less risk-averse or more risk-loving he or she is. Furthermore, the older the respondent is, the safer he or she feels when investing in stocks $(\alpha=1 \%)$. A significant direct relationship was also found between older age and greater confidence.

In one's own investment opinions than those of financial analysts and/or third parties (Table 2). Interestingly, most respondents (78\%) stated that they would feel more comfortable investing in green bonds to achieve a low-carbon Peruvian economy, while also feeling more confident (safe) when it comes to investing in stocks in pursuit of private returns (significance level of $5 \%$ ). Evidence of loss aversion was found among respondents faced with the decision to invest a significant monetary amount (US\$100,000) in a single financial instrument; the majority chose low-risk instruments despite their feeling of confidence in investing in stocks (Table 2). In turn, a close relationship of $r=0.482$ was found between the contribution of investment in green bonds to environmental quality and the comfort (satisfaction) that the respondents would feel when investing in instruments such as green bonds to facilitate Peru in becoming a low carbon economy. ( $\alpha=1 \%)$. With regard to financial cognitive biases, conservation bias - the use of old information in the mind (Rahim et al., 2019) - is observed, since people trust their own investment views more than that of 
financial analysts, feeling comfortable about their investment decisions in instruments such as green bonds for the sustainability of environmental assets in Peru ( $r=0.455, \alpha=1 \%$, table 2$)$.

Table 3: Relationship between Education and Risk Behavior

\begin{tabular}{llllll}
\hline Education & \multicolumn{2}{l}{ How Risk Averse are you? } & Total \\
\cline { 2 - 5 } & Not Risk Averse & Neutral & $\begin{array}{l}\text { Somewhat } \\
\text { Averse }\end{array}$ & $\begin{array}{l}\text { Highly } \\
\text { Averse }\end{array}$ & \\
\hline Undergraduate & 0 & 1 & 10 & 2 & 13 \\
Bachelor's degree & 0 & 4 & 7 & 4 & 15 \\
Licentiate degree & 2 & 0 & 4 & 0 & 6 \\
Master's degree & 2 & 5 & 1 & 1 & 9 \\
Doctor's degree & 2 & 3 & 3 & 3 & 11 \\
Total & 6 & 13 & 25 & 10 & 54 \\
\hline
\end{tabular}

Chi squared 22.838, P-value $=0.029$

According to the Chi-square statistic, there is a relationship between a person's level of education and their attitude toward risk at a significance level of 5\% (Table 3). The Spearman correlation reinforces this significant negative association (Table 2).

Table 4: Relationship between Education, Financial Risk, and Environmental Risk

\begin{tabular}{llllll}
\hline Education & \multicolumn{2}{l}{$\begin{array}{l}\text { Is there a Relationship between Financial Risk and } \\
\text { Environmental Risk? } \\
\text { None }\end{array}$} & Little & Moderate & Strong \\
& 0 & 3 & 8 & 2 & 13 \\
\hline Undergraduate & 0 & 5 & 10 & 0 & 15 \\
Bachelor's degree & 0 & 1 & 5 & 0 & 6 \\
Licentiate degree & 1 & 0 & 5 & 3 & 9 \\
Master's degree & 1 & 0 & 4 & 6 & 11 \\
Doctor's degree & 2 & 9 & 32 & 11 & 54 \\
Total & & &
\end{tabular}

Chi squared 22.825, P-value $=0.029$

Clearly, people formally educated in both finance and environmental science perceive a link between financial risk and environmental risk, $\alpha=5 \%$ (Table 4).

Table 5: Relationship between Education and Own Investment Opinions

\begin{tabular}{llllll}
\hline Education & \multicolumn{5}{l}{$\begin{array}{l}\text { I Feel More Confident in my Own Investment Views than the Total } \\
\text { Opinions of Financial Analysts, Friends and Family? }\end{array}$} \\
& Disagree & Somewhat Agree & Agree & Totally Agree \\
\hline Undergraduate & 0 & 6 & 6 & 1 & 13 \\
Bachelor's degree & 5 & 8 & 2 & 0 & 15 \\
Licentiate degree & 1 & 2 & 3 & 0 & 6 \\
Master's degree & 1 & 5 & 2 & 1 & 9 \\
Doctor's degree & 0 & 2 & 4 & 5 & 11 \\
Total & 7 & 23 & 17 & 7 & 54
\end{tabular}

Chi squared 25.883, P-value $=0.011$

When it came to investment decisions, a relationship was found between the level of education and one's own opinions according to the Chi square, at a significance level of 5\% (Table 5).

Causal Relationship between Behavioral Finance and Environmental Assets: The relationship between the behavioral finance of green bonds and their contribution to environmental quality and/or reduction of pollution was investigated based on the perception of the respondents out of four options: pessimistic, neutral, somewhat optimistic, and very optimistic (Table 6). There is an association between market 
sentiment and risk; Paraboni et al. (2018) detect a negative relationship between risk aversion and the satisfaction (comfort) that a person would feel when investing in-stock instruments.

Table 6: Distribution of the Processing of the Variable Investment in Green Bonds. Summary of Case Processing

\begin{tabular}{lll}
\hline & N & $\begin{array}{l}\text { Marginal } \\
\text { Percentage }\end{array}$ \\
\hline $\begin{array}{l}\text { Do you think that investing in greenNeutral } \\
\text { bonds will contribute to Somehow optimistic }\end{array}$ & 9 & $16.7 \%$ \\
environmental quality and/or Very optimist & 31 & $57.4 \%$ \\
reduce pollution? & 14 & $25.9 \%$ \\
Valid & 54 & $100.0 \%$ \\
Lost & 0 & \\
Total & 54 & \\
Subpopulation & $51^{\text {a }}$ & \\
The & &
\end{tabular}

a. The dependent variable only has an observed value in 50 (98.0\%) subpopulations.

* The reference category is "very optimistic."

Table 7: Multinomial Logistic Regression Model

A. Pseudo R- Squared

\begin{tabular}{ll}
\hline Cox and Snell & $\mathbf{4 8 8}$ \\
\hline Nagelkerke &, 570 \\
McFadden &, 346 \\
\hline
\end{tabular}

B. Model Fit Information

\begin{tabular}{lllcr}
\hline Model & Model Fit Criterion & \multicolumn{3}{l}{ Likelihood Ratio Tests } \\
& $\mathbf{- 2 ~ l o g}$ Likelihood & Chi-Squared & Df & Sig. \\
\hline Intersection only & 103,073 & & & \\
Final & 66,970 & 36,103 & 14 &, 001
\end{tabular}

C. Goodness of Fit

\begin{tabular}{llll}
\hline & Chi-squared & Df & Sig. \\
\hline Pearson & 81,775 & 86 &, 609 \\
Deviation & 65,583 & 86 &, 950 \\
\hline According to the
\end{tabular}

According to the goodness of fit (Table 7c.), the null hypothesis of the logistic probability distribution (PValue $>5 \%$ ) is not rejected.

D. Likelihood Ratio Tests

\begin{tabular}{lllll}
\hline Effect & Model Fit Criteria & \multicolumn{2}{l}{ Likelihood Ratio Tests } & \\
& $\begin{array}{l}\text {-2 Log Likelihood of } \\
\text { Reduced Model }\end{array}$ & Chi-Squared & Gl & Sig. \\
\hline Intersection & 85,562 & 18,593 & 2 &, 000 \\
Age & 68,228 & 1,258 & 2 &, 533 \\
Education & 67,487 &, 517 & 2 &, 772 \\
Bond rating & 80,120 & 13,150 & 2 &, 441 \\
Risk attitude & 68,607 & 1,637 & 2 &, 307 \\
Stocks & 69,329 & 2,360 & 2 &, 258 \\
Trusted & 69,676 & 2,706 & 2 &, 063
\end{tabular}

The chi-square statistic is the difference in the -2 log-likelihoods between the final model and the reduced model. The reduced model is formed by omitting an effect from the final model. The null hypothesis is that all the parameters of that effect are 0 . 
Multinomial logistic regression is used to test the contribution of behavioral finance in investing in green environmental bonds. It was found that the model is significant and that the independent variables explain the investment in environmental green bonds between $49 \%$ and $57 \%$ according to the Cox and Snell and Nagelkerke statistics, respectively (Table $7 \mathrm{a}, \mathrm{b}$ ). Specifically, the variables "green bonds rating" and "feeling of comfort (satisfaction) when investing in instruments such as green bonds" are significant (Table $7 \mathrm{~d}$ ). In this study an online questionnaire was used; following Endress (2018), the criterion for the selection of the sample was to ensure the diversification of the respondents in terms of age, gender, and level of education. Following Thaler (1999) and Puaschunder (2018), a "nudge" was applied via the question "how satisfied or comfortable would you feel investing in instruments such as green bonds for Peru to achieve a low-carbon economy," to which the respondents answered positively. According to Ferreira and Dickason-Koekemoer (2019), the correlation between risk tolerance and level of education yielded a significant result $(r=-0.154)$ and a small linear association, coinciding with previous research (Ferreira \& Dickason-Koekemoer, 2019).

The former study also found that more years of schooling allows people to better assess the risks and benefits than fewer years of schooling. In the Peruvian case, a significant negative correlation was also found between the level of education and risk aversion $(r=-0.338)$; that is, the higher one's level of education, the less riskaverse (or the more risk-tolerant) their behavior. According to Salem (2019), Arab women are more riskaverse than men. In the Peruvian case, gender was found to have no effect on risk aversion when making investment decisions. Rahim et al. (2019) found that conservatism bias has positive impacts on the investment decisions of individual investors in the Pakistan stock exchange; the variation explained by the independent variables of the logistic regression is around $50 \%$ and $65 \%$ using the Cox \& Snell R-square and the Nagelkerke R-square, respectively. For the Peruvian case, it was found that the independent variables explain between 49\% (Cox \& Snell R-square) and 57\% (Nagelkerke R-square) of the investment in environmental green bonds.

\section{Conclusion}

Peru has ventured into the green bond market to boost investment in environmental projects. This study aims to encourage more of this kind of investment based on the contribution of behavioral finance to the sustainability of environmental assets in terms of emotionally complementing people's investment decisions. A negative correlation was found between the level of education and risk aversion; that is, the more education a person has, the more risk-tolerant they will be. In turn, the less risk-averse the investor, the more satisfaction or comfort they will derive from stock instruments such as green bonds that aid Peru in becoming a low carbon economy. The perception of conservation bias was detected; that is, people trust their own investment views more than those of financial analysts, feeling comfortable in their decisions to invest in instruments such as green bonds for the sustainability of environmental assets. Loss aversion is validated in the decision to invest a sizeable monetary amount (100 thousand dollars) in a single financial instrument, whereby most investors choose low-risk instruments despite the feeling of safety or confidence to invest in stocks. The perception that investing in green bonds improves environmental quality is explained by the variables of "green bonds rating" and "feeling of comfort (satisfaction) investing in instruments such as green bonds." Finally, a "nudge" was given via the question "how satisfied or comfortable would you feel investing in instruments such as green bonds for Peru to become a low carbon economy," to which those involved responded positively.

Acknowledgments: The author wishes to thank Jeffrey Ramón for his assistance in part of the research and online survey.

\section{References}

Ahmad, Z., Ibrahim, H. \& Tuyon, J. (2017). Institutional investor behavioral biases: syntheses of theory and evidence. Management Research Review, 40(5), 578-603.

Bolsas \& Mercados Españoles. (2017). AIAF admite a cotización la emisión de bonos verdes de ADIF-Alta Velocidad.

Candraningrat, I., Salim, U., Indrawati, N. \& Ratnawati, K. (2018). Influence of Information Infrastructure and Disposition Effect in Decision of Investment: Experimental Study on Investor Behavior at Indonesia 
Stock Exchange Representative on Denpasar, Bali. International Review of Management and Marketing, 8(3), 59-68.

Climate Bonds Initiative. (2019). América Latina y el Caribe: Estado del mercado de las finanzas.

Endress, T. (2018). Deliberated Intuition' in Stock Price Forecasting. Economics and in Stock Price Forecasting. Economics and Sociology, 11(3), 11-27.

Ferreira, S. \& Dickason-Koekemoer, Z. (2019). The Relationship Between Depositor Behaviour and Risk Tolerance in a South African Context. Advances in Decision Sciences, 23(3), 1-19.

Green Finance Initiative. (2018). Accelerating green finance. A report to government by the Green Finance Taskforce. U K.

Gupta, K. (2018). Environmental Sustainability and Implied Cost of Equity: International Evidence. Journal of Business Ethics, 147(2), 343- 365.

Howarth, C. \& Roberts, B. (2018). The Role of the UK Green Deal in Shaping Pro-Environmental Behaviours: Insights from Two Case Studies. Sustainability, 10(6), 1-18.

Kahneman, D. \& Tversky, A. (1979). Prospect theory: An analysis of decision under risk. Econometrica, 47(2), 263-291.

Kankipati, A. \& Sireesha, M. (2017). An Analysis of Recent Developments in Neuro Financing and Carbon Financing in India. IJRDT, 7(6), 18-21.

Martins, E., Vidal, F., De Pádua, A., Pérez, B. \& Hiromi, M. (2018). Behavioral finance and games: simulations in the academic environment. R. Cont. Fin, 29(77), 297-311.

Paraboni, A. L., Righi, M. B., Vieira, K. M. \& Da Silveira, V. G. (2018). The Relationship between Sentiment and Risk in Financial Markets. Brazilian Administration Review, 15(1), 2.

Plataforma Mexicana de Carbono. (2018). Guía de bonos verdes para el Perú. MÉXICO2.

Puaschunder, J. (2018). Nudgitize me! A Behavioral finance approach to minimize losses and maximize profits from heuristics and biases. Journal of Organizational Psychology, 18(1), 46-66.

Rahim A., Shah M. \& Aamir A. (2019). Impact of conservatism bias effect on investment decisions of Pakistani stock investors. City University Research Journal, 9(1), 85-97.

Salem, R. (2019). Examining the investment behavior of Arab women in the stock market. Journal of Behavioral and Experimental Finance, 22(C), 151-160.

Sarmiento, J., Rendon, J., Sandoval, J. S. \& Cayon, E. (2019). An alternative measure of disposition effect: Reevaluating the evidence among sophisticated investors. Journal of Behavioral and Experimental Finance, 24(C).

Thaler, R. (1999). The end of behavioral finance. Financial Analysts Journal, 55(6), 12-17. 